\title{
Correlation of Sleep Disorders with Suicidal Ideation in Patients with Major Depressive Disorder
}

(D) Ender Kaya

University of Health Sciences Turkey, Prof. Dr. Cemil Taşşıoğlu City Hospital, Clinic of Psychiatry, İstanbul, Turkey

\section{Abstract}

Objective: This study aimed to investigate the correlation of subjective sleep disorders with suicidal ideation in patients with major depressive disorder (MDD).

Methods: The study included 60 patients attending at University of Health Sciences Turkey, Prof. Dr. Cemil Tașçıoğlu City Hospital, Clinic of Psychiatry with diagnosis of MDD according to the Diagnostic and Statistical Manual of Mental Disorders-V diagnostic criteria. Cases completed a sociodemographic data form, Beck Depression Inventory (BDI), Suicidal Ideation scale (SIS), and Pittsburgh Sleep Quality Index (PSQI).

Results: Correlation analysis identified positive significant correlations between number of disease attacks with PSQI and SIS points. Positive significant correlations were found between SIS total points and PSQI-1, PSQI-5, PSQI-6, PSQI-T, and BDI points. Regression analysis identified that PSQI-5 and PSQI-T points were each a predictor for SIS values.

Conclusion: Data obtained in this study confirmed that sleep disorders may have an effect on suicidal thoughts among MDD cases.

Keywords: Major depressive disorder, sleep disorder, suicidal ideation

\section{INTRODUCTION}

Major depressive disorder (MDD) is the most common mood disorder included under the heading of depression disorders in the Diagnostic and Statistical Manual of Mental Disorders (DSM)-V classification, which seriously disrupts functioning and may occur as a single attack or recurring attacks (1). It is a serious mental disorder that may be observed commonly, with high rates of becoming chronic and recurrence, causing physical and psychosocial disability (2). Risk factors for suicide in MDD are reported to be hopelessness, alcohol dependence or alcohol abuse, low social and occupational functioning levels, and poor perceived social support (3). In addition, an association is reported between sleep disorders with suicidal ideation and behavior (4). Risk factors in terms of suicide are accepted as insomnia, hypersomnia, nightmares, and panic attacks during sleep (5).
In Turkey, the correlation between sleep disorder and suicidal thoughts in MDD is limited to studies by Ağargün et al. (6) Agargun and Cartwright (7) stated that sleep disorders were associated with suicidal ideation in depression. This led to the curiosity about the relationships between disease attack frequency and disease duration, which may determine the progress of MDD, with both sleep disorders and suicidal ideation.

This study aimed to investigate the relationship between sleep disorders with suicidal ideation in patients with MDD. Our main hypothesis is that sleep disorder in MDD is associated with suicidal ideation. Our secondary hypothesis is that sleep disorder is a determinant for suicidal ideation.

\section{METHODS}

The study included 60 patients diagnosed with MDD according to the DSM-V diagnostic criteria, who are attending 
at Prof. Dr. Cemil Taşçıoğlu City Hospital Psychiatric Clinic. The research was permitted by the Clinical Research Ethics Committee (12.10.2020/396) of the hospital and abided by the principles stated in the Helsinki Declaration. Participants were informed about this study and verbal and written consent were obtained.

Patients with past or current bipolar disorder, psychotic disorders, alcohol and substance abuse disorders, or severe neurological diseases were excluded from the study. Diagnosis of patients included in the study was confirmed with the semi-structured clinical interview form for DSM (SCID)-5 interview. Patients completed the Beck Depression Inventory (BDI), Pittsburgh Sleep Quality Index (PSQI), and Suicidal Ideation Scale (SIS).

\section{Scales Used}

SCID-5: This is a structured interview form developed by First (8). Turkish adaptation and reliability studies were performed by Elbir et al. (9).

Sociodemographic information form: This form includes questions about the patients' demographic characteristics (age, sex, educational status, year of onset of depression, number of time depression was experienced, and hospital admissions due to depression).

BDI: This scale measures the bodily, affective, and cognitive symptoms observed in depression. It is a self-report scale containing 21 symptom categories. Highest point that can be obtained is 63. High total points show the severity of depression. It was developed by Beck et al. (10), and validity and reliability studies for our country were performed by Hisli (11).

SIS: It comprises 17 questions in which the questions are answered as yes/no, and the total score from the scale varies between $0-17$. The SIS is a self-reported test that was developed in 1989 by Levine et al. (12). This scale aims to determine the intensity of suicidal ideation and Turkish validity, and reliability studies were performed by Dilbaz et al. (13). It comprises 17 questions with yes/no answers, and total points vary from 0 to
17. High points indicate the presence of pronounced suicidal ideation.

PSQI: The PSQI was developed by Buysse et al. (14). PSQI is a sleep survey assisting to determine the quality of sleep, amount of sleep, and presence and severity of sleep disorders experienced by a person within the last month. Turkish validity and reliability studies were performed by Ağargün et al. (15). This scale contains 19 items and comprises seven subcomponents of subjective sleep quality (PSQI-1), sleep latency or the duration to fall asleep (PSQI-2), sleep duration (PSQI-3), habitual sleep efficiency (PSQI-4), sleep disturbance (PSQI-5), sleep medication use (PSQI-6), and daytime functioning (PSQI-7). Total PSQI score is obtained by adding the seven subscores, and is between 0 and 21. PSQI total score definitively differentiates those who sleep well (PSQI total score of $\leq 5$ ) from those who sleep poorly (PSQI of $>5$ ).

\section{Statistical Analysis}

When analyzing findings obtained in the study, statistical analyses used the International Business Machines Corporation Statistical Package for the Social Sciences Statistics 22 program (IBM SPSS, Turkey). Pearson correlation analysis was used to investigate the correlations between parameters which fit normal distribution. Spearman correlation analysis was used to investigate the correlations between parameters without normal distribution. Linear regression analysis was used to assess the effect of PSQI subscales on SIS.

\section{RESULTS}

The study included 38 female and 22 male patients with MDD. Mean age of patients was $38.24 \pm 10.28$ years with mean educational duration of $11.24 \pm 4.36$ years.

Correlations of PSQI total, SIS total, BDI total, and disease onset age, disease attack numbers (DAN), and disease duration for patients with MDD are given in Table 1. Positive significant correlations were identified between DAN with PSQI-T, SIS, and BDI points.

\begin{tabular}{|l|l|l|l|l|l|}
\hline \multicolumn{6}{|l|}{ Table 1. Correlations between PSQI, and BDI points of patients with MDD with disease characteristics } \\
\hline & PSQI & SIS & BDI & DAN & DD \\
\hline PSQI & 1 & $0.316^{*}$ & $0.462^{* *}$ & $0.284^{*}$ & 0.098 \\
\hline SIS & 1 & $0.582^{* *}$ & $0.308^{*}$ & 0.102 \\
\hline BDI & $0.316^{*}$ & $0.582^{* *}$ & 1 & $0.535^{* *}$ & $0.462^{* *}$ \\
\hline DAN & $0.462^{* *}$ & $0.308^{*}$ & $0.535^{* *}$ & 1 & $0.567^{* *}$ \\
\hline DD & $0.284^{*}$ & 0.102 & $0.462^{* *}$ & $0.567^{*}$ & 1 \\
\hline $\begin{array}{l}* \\
\text { * }<0.05, * * \\
\text { Disease duration, MDD: Major depressive disorder }\end{array}$ & 0.098 & \multicolumn{5}{|l|}{} \\
\hline
\end{tabular}


Correlations between SIS subscales and total points, PSQI subscales and total points, and BDI for patients with MDD are given in Table 2. Positive significant correlations were identified between SIS total points with PSQI-1, PSQI-5, PSQI-6, PSQI-T, and BDI points.

Only PSQI-5 and PSQI-T dimensions was statistically significant when the effect of PSQI subscale points on SIS total points is assessed with linear regression analysis. Analysis of these dimensions identified $R^{2} 0.416$ and corrected $R^{2} 0.216$, and these were statistically significant $(F: 18,630, p=0.001)$ (Table 3).

\section{DISCUSSION}

In this study, disrupted sleep quality in patients with MDD is identified to be associated with suicidal ideation.

With recurrent depression, insomnia may worsen just before the next depressive episode begins. Insomnia can also pose a significant risk for new depression attacks. Armitage stated that permanent sleep problems, especially insomnia, elevated the risk of requiring increased medication, in addition to the risk of recurrence and poor progression (16). In our study, DAN was identified to be significantly correlated with both disrupted sleep quality and suicidal ideation. Additionally, a significant correlation was identified between the PSQI-6 dimension with depression and severity of suicidal ideation. The high risk of recurrence of the disease in depression, where sleep disorders are at the forefront, is a factor that increases the suicide attempt of sleep disturbance independent to the disease (17). In this context, in the cycle of insomnia and depression which may have double-sided effects (18), treatment of sleep disorders may reduce the number of recurrences (19).

Poor sleep quality, early insomnia, and lack of restful sleep were reported to be associated with suicide risk (20). In addition, studies investigating the correlations between sleep, depression, and suicidal tendency variables reported that sleep disorders like difficulty falling asleep, early waking, poor sleep quality, and nightmares were associated with depressive mood and suicidal ideation $(21,22)$. In our study, disruption of both subjective sleep quality and total sleep quality were identified to be correlated with suicidal ideation in patients with MDD in accordance with the literature. It was reported that sleep onset insomnia problems were associated with suicidal ideation in patients with MDD (23). In our study, when early insomnia symptoms as assessed by the PSQI-5 dimension are evaluated, they were identified to be correlated with suicidal ideation, supporting this data. In this context, the correlation of sleep disorders with suicidal ideation may be explained by patients having difficulty falling asleep due to thoughts like continuous guilt and worries, in addition to frequent disturbance of sleep (24). Moreover, nighttime is an active time due to disrupted

Table 2. Correlations between BDI and SIS subscales and total points with PSQI subscales and total points for patients with MDD

\begin{tabular}{|c|c|c|c|c|c|c|c|c|c|c|}
\hline & SIS & PSQI-1 & PSQI-2 & PSQI-3 & PSQI-4 & PSQI-5 & PSQI-6 & PSQI-7 & PSQI-T & BDI \\
\hline SIS & 1 & $0.248^{*}$ & 0.132 & -0.028 & 0.122 & $0.486^{* *}$ & $0.422^{* *}$ & 0.072 & $0.386^{*}$ & $0.582^{* *}$ \\
\hline PSQI-1 & $0.248^{*}$ & 1 & $0.484 * *$ & $0.424 * *$ & $0.292^{*}$ & $0.302^{*}$ & $0.226^{*}$ & $0.442 * *$ & $0.628 *$ & $0.424 * *$ \\
\hline PSQI-3 & -0.028 & $0.424 * *$ & $0.382^{*}$ & 1 & $0.562^{* *}$ & 0.197 & 0.202 & 0.224 & $0.528 * *$ & 0.123 \\
\hline PSQI-4 & 0.122 & $0.292^{*}$ & $0.432^{*}$ & $0.562^{* *}$ & 1 & $0.325^{*}$ & $0.302^{*}$ & 0.256 & $0.667^{* *}$ & 0.286 \\
\hline PSQI-6 & $0.422^{* *}$ & $0.226^{*}$ & $0.493 * *$ & 0.202 & $0.302^{*}$ & 0.198 & 1 & 0.182 & $0.425^{* *}$ & $0.482^{* *}$ \\
\hline PSQI-7 & 0.072 & $0.442^{* *}$ & $0.382^{*}$ & 0.224 & 0.256 & $0.467 * *$ & 0.182 & 1 & $0.578 * *$ & 0.145 \\
\hline PSQI-T & $0.386^{*}$ & $0.628^{*}$ & $0.728 * *$ & $0.528 * *$ & $0.667^{* *}$ & $0.534 * *$ & 0.425 & $0.578^{* *}$ & 1 & $0.462^{* *}$ \\
\hline BDI & $0.582^{* *}$ & $0.424^{*}$ & $0.385^{*}$ & 0.123 & 0.286 & $0.592^{* *}$ & 0.482 & 0.145 & $0.462^{* * *}$ & 1 \\
\hline
\end{tabular}

Table 3. Linear regression analysis results for variables predicting SIS total points

\begin{tabular}{|l|l|l|l|l|l|l|}
\hline Dependent variable & Predictors & B & Std E & Beta & T & p \\
\hline SIS & PSQI-5 & 1.398 & 0.322 & 0.524 & 3.423 \\
\hline & PSQI-T & 2.424 & 0.566 & 0.237 & 3.752 \\
\hline SIS: Suicidal Ideation Scale, PSQI: Pittsburgh Sleep Quality Index
\end{tabular}


circadian rhythms in depression (25) along with inadequate problem-solving capacity caused by lack of sleep (26) which may increase suicidal ideation.

Regression analysis in our study identified the PSQI-5 (sleep disturbance) subdimension and PSQI-T points were each predictors of suicidal ideation. This finding supports previous studies. That is, the deterioration of sleep quality in MDD may affect suicidal thoughts through mood dysregulation $(4,7)$.

\section{CONCLUSION}

Our results revealed a correlation between disrupted sleep quality and suicidal ideation in MDD. Sleep disorder in MDD may be a predictor for passive suicidal ideation. Additionally, disrupted sleep quality in patients with MDD was associated with the number of disease attacks in the past.

Sleep disturbances may be associated with clinically significant suicidal thoughts and specific suicidal plans, especially in outpatients with active suicidal thoughts and depressive disorder. Therefore, sleep disorders should be taken into account in the clinical evaluation of depressive patients in terms of suicide risk. Improving sleep quality may prevent the development of depressive symptoms and reduce the likelihood of suicidal ideation. Moreover, it is not possible to determine the cause-outcome relationship due to the cross-sectional design of our study.

\section{Ethics}

Ethics Committee Approval: The research was permitted by the Clinical Research Ethics Committee (12.10.2020/396) of the hospital and abided by the principles stated in the Helsinki Declaration.

Informed Consent: Participants were informed about this study and verbal and written consent were obtained.

Peer-review: Externally peer-reviewed.

Financial Disclosure: The author declared that this study received no financial support.

\section{REFERENCES}

1. Amerikan Psikiyatri Birliği, Ruhsal Bozuklukların Tanısal ve Sayımsal El kitabı, Beşinci Baskı (DSM-5) Tanı Ölçütleri Başvuru Elkitabından, çev. Köroğlu E, Hekimler Yayın Birliği, Ankara, 2013.

2. Kessler RC, Berglund P, Demler O, Jin R, Koretz D, Merikangas KR, et al. The epidemiology of major depressive disorder: results from the National Comorbidity Survey Replication (NCS-R). JAMA 2003;289:3095105.

3. Sokero TP, Melartin TK, Rytsälä HJ, Leskelä US, Lestelä-Mielonen PS, Isometsä ET. Suicidal ideation and attempts among psychiatric patients with major depressive disorder. J Clin Psychiatry 2003;64:1094-100.
4. Bernert RA, Joiner TE Jr, Cukrowicz KC, Schmidt NB, Krakow B. Suicidality and sleep disturbances. Sleep 2005;28:1135-41.

5. Pigeon WR, Pinquart M, Conner K. Meta-analysis of sleep disturbance and suicidal thoughts and behaviors. J Clin Psychiatry 2012;73:e11607.

6. Ağargün MY, Kara H, Solmaz M. Sleep disturbances and suicidal behavior in patients with major depression. J Clin Psychiatry 1997;58:249-51.

7. Agargun MY, Cartwright R. REM sleep, dream variables and suicidality in depressed patients. Psychiatry Res 2003;119:33-9.

8. First MB. Structured clinical interview for DSM V Axis I Disorders (SCID I). Clinical Version. American Psychiatric Press Washington DC; 2015.

9. Elbir M, Alp Topbaş Ö, Bayad S, Kocabaș T, Topak OZ, Çetin \$, et al. DSM-5 Bozuklukları için Yapılandırılmıș Klinik Görüșmenin Klinisyen Versiyonunun Türkçeye Uyarlanması ve Güvenilirlik Çalıșması [Adaptation and Reliability of the Structured Clinical Interview for DSM5-Disorders - Clinician Version (SCID-5/CV) to the Turkish Language]. Turk Psikiyatri Derg 2019;30:51-6.

10. Beck AT, Ward CH, Mendelson M, Mock J, Erbaugh J. An Inventory for Measuring Depression. Arch Gen Psychiatry 1961;4:561-71.

11. Hisli N. Beck Depresyon Envanterinin üniversite öğrencileri için geçerliği, güvenirliği. Psikoloji Dergisi 1989;7:3-13.

12. Levine S, Ancill RJ, Roberts AP. Assessment of suicide risk by computerdelivered self-rating questionnaire: preliminary findings. Acta Psychiatr Scand 1989;80:216-20.

13. Dilbaz N, Holat H, Bayam G, Tüzer T. Intihar düșüncesi ölçeğinin geçerlilik ve güvenirliği. 31. Ulusal Psikiyatri Bilimler Kongresi Bilimsel Çalıșma Kitabı 1995.p.40-1.

14. Buysse DJ, Reynolds CF 3rd, Monk TH, Berman SR, Kupfer DJ. The Pittsburgh Sleep Quality Index: a new instrument for psychiatric practice and research. Psychiatry Res 1989;28:193-213.

15. Ağargün MY, Kara H, Anlar Ö. Pittsburgh Uyku Kalitesi Indeksi'nin Geçerliliği ve Güvenirliği. Turk Psikiyatri Derg 1996;7:107-15.

16. Armitage R. The effects of antidepressants on sleep in patients with depression. Can J Psychiatry 2000;45:803-9.

17. Agargun MY, Beşiroğlu L. Sleep and suicidality: do sleep disturbances predict suicide risk? Sleep 2005;28:1039-40.

18. Franzen PL, Buysse DJ. Sleep disturbances and depression: risk relationships for subsequent depression and therapeutic implications. Dialogues Clin Neurosci 2008;10:473-81.

19. Ohayon MM, Roth T. Place of chronic insomnia in the course of depressive and anxiety disorders. J Psychiatr Res 2003;37:9-15.

20. Bernert RA, Turvey CL, Conwell Y, Joiner TE Jr. Association of poor subjective sleep quality with risk for death by suicide during a 10year period: a longitudinal, population-based study of late life. JAMA Psychiatry 2014;71:1129-37.

21. Bernert RA, Joiner TE. Sleep disturbances and suicide risk: A review of the literature. Neuropsychiatr Dis Treat 2007;3:735-43.

22. Riedel BW, Lichstein KL. Insomnia and daytime functioning. Sleep Med Rev 2000;4:277-98.

23. Smith MT, Perlis ML, Haythornthwaite JA. Suicidal ideation in outpatients with chronic musculoskeletal pain: an exploratory study of the role of sleep onset insomnia and pain intensity. Clin J Pain 2004;20:111-8.

24. Güleç C. Belirti ve bulgular: Teșhis. Depresyon: çağdaş tedavi yaklașımları. Ankara: Servier; 1991.p.3-5. 
25. Selvi Y, Aydin A, Boysan M, Atli A, Agargun MY, Besiroglu L. Associations between chronotype, sleep quality, suicidality, and depressive symptoms in patients with major depression and healthy controls. Chronobiol Int 2010;27:1813-28.
26. Fortier-Brochu E, Beaulieu-Bonneau S, Ivers H, Morin CM. Insomnia and daytime cognitive performance: a meta-analysis. Sleep Med Rev 2012;16:83-94. 